Danuta Piekarz ${ }^{1}$

Uniwersytet Jagielloński

\title{
"Ubodzy, a wzbogacający wielu” (por. 2 Kor 6, 10). Ubóstwo Chrystusa i wiernych w nauczaniu św. Pawła
}

Kto szukałby w Listach Pawłowych wielu typowych wskazówek dotyczących ewangelicznego ubóstwa, podejścia do dóbr materialnych i tym podobnych, szybko się rozczaruje. Jak zobaczymy, wyraźne wskazania tego rodzaju znajdziemy niemal wyłącznie w 1 Liście do Tymoteusza, w którego przypadku autorstwo Pawłowe jest co najmniej dyskusyjne. Co więcej, słowo „bogactwo" występuje u Pawła najczęściej w sensie ubogacenia nas przez Boga, zatem jest to bogactwo nie tylko dozwolone, ale jak najbardziej pożądane. Nie oznacza to jednak, że Apostoł nie ma niczego do powiedzenia na interesujący nas temat, a jedynie, że czyni to w sposób... dość nietypowy.

\section{Ubóstwo Chrystusa}

Charakterystycznym dla Pawła sposobem motywowania wiernych do określonych postaw moralnych jest ukazywanie wzoru w Chrystusie.

1 Danuta Piekarz, biblistka i italianistka, wykładowca w Zakładzie Italianistyki Uniwersytetu Jagiellońskiego w Krakowie, a także na Uniwersytecie Papieskim Jana Pawła II i w Kolegium Filozoficzno-Teologicznym Polskiej Prowincji Dominikanów. Autorka książek i artykułów z zakresu biblistyki i językoznawstwa, tłumaczka książek i konferencji włoskich autorów. E-mail: danuta.piekarz@uj.edu.pl. 
Wierni wpatrzeni w Mistrza winni naśladować Jego dążenia i postępowanie. W kwestii ubóstwa fundamentalne okazują się dwa zdania, zapisane przez Apostoła w różnych listach i różnych kontekstach, a jednak wykazujące pewne podobieństwo. Pierwsza wypowiedź pojawia się w kontekście składki dla ubogich z Jerozolimy (będziemy mówić o niej dalej), zatem dotyczy głównie kwestii materialnych w życiu wiernych, choć nie ogranicza się do nich. Paweł pisze do Koryntian w 2 Kor 8, 9: „Znacie przecież łaskę Pana naszego, Jezusa Chrystusa, który będąc bogatym, dla was stał się ubogim, aby was ubóstwem swoim ubogacić”. Komentatorzy zadają sobie pytanie, co oznacza owo „stanie się ubogim” (ptoheuo - hapax legomenon Nowego Testamentu): czy chodzi o przejście z chwały nieba do kondycji człowieka, czy też o wybór ubogiego życia na ziemi? Oczywiście obie wersje mogą się uzupełniać. Pewny jest natomiast paradoksalny fakt, że owo ubóstwo Chrystusa, przeżywane w ludzkiej naturze, stało się źródłem bogactwa wiernych. Apostoł nie musi precyzować natury tego bogactwa, gdyż była ona oczywista dla adresatów: przez swoje uniżenie Chrystus ubogacił nas życiem Bożym; może szczególnie należałoby tu podkreślić dary Ducha i charyzmaty ${ }^{2}$, bowiem wcześniej Paweł pisał również do Koryntian, że w Chrystusie „zostaliście wzbogaceni we wszystko: we wszelkie słowo i wszelkie poznanie" (1 Kor 1,5).

Drugi interesujący nas fragment pochodzi ze słynnego - przedpawłowego zdaniem dzisiejszych komentatorów - hymnu o kenozie (interesują nas wersety Flp 2, 7n), ukazującego w Chrystusie wzór dla Filipian krytykowanych przez Apostoła za wywyższanie się nad innych. Chrystus, jak pisze Paweł, „ogołocił samego siebie” - heauton ekenosen. Czasownik kenoo w Nowym Testamencie jest używany tylko przez Pawła, a tylko w tym miejscu występuje z zaimkiem zwrotnym w pozycji emfatycznej, co podkreśla dobrowolność ofiary Chrystusa3. I choć w tym hymnie nie mówi się wprost o ubogaceniu wiernych, chyba warto zauważyć, że kenoo (opróżnić) jest antonimem innego czasownika jakże bliskie-

Por. G. Lorusso, La Seconda Lettera ai Corinzi, Bologna 2007, s. 218 (Scritti delle Origini Cristiane, 8).

3 Por. F. Bianchini, Lettera ai Filippesi, Milano 2010, s. 53 (Nuova Versione della Bibbia dai Testi Antichi, 47). 
go św. Pawłowi - pleroo (napełnić) ${ }^{4}$. Jeśli więc spojrzymy całościowo na teologię Apostoła, można by powiedzieć, opierając się na stwierdzeniu z 2 Kor 8, 9, że Chrystus, który „stał się ubogim, by nas ubogacić”, „ogołocił siebie”, by nas „napełnić”. Na poparcie takiej interpretacji można przytoczyć Ef 4, 10, łączący, podobnie jak hymn z Flp, uniżenie i wywyższenie Chrystusa: „Ten, który zstąpił, jest i Tym, który wstąpił ponad wszystkie niebiosa, aby wszystko napełnić”.

Ogołocenie i postawa ubóstwa Chrystusa jest wyrażona w hymnie z Flp przez jeszcze jedno wyrażenie: „uniżył samego siebie” (etapeinosen heauton). Także i tu sam Chrystus dobrowolnie przyjmuje tę postawę, co więcej, komentatorzy podkreślają, że tapeinoo zawsze oznacza w NT postawę wypływającą z posłuszeństwa i czci wobec Boga.

Święty Paweł wskazuje więc, że Chrystus stał się ubogim, rezygnując w swym wcieleniu z oznak Boskiej chwały. Można by powiedzieć, że w swym ogołoceniu wytworzył w sobie przestrzeń na przyjęcie ludzkiej natury, by móc napełnić człowieka Boskimi darami. Jak dalej zobaczymy, ubóstwo człowieka ma za cel wytworzenie w sobie przestrzeni na przyjęcie tych darów, by także móc przekazywać je innym.

\section{Ubóstwo Apostoła}

Skoro Chrystus wyrzekł się blasku chwały dla ludzi, a więc również dla Pawła, to Paweł postanawia stać się ubogim dla Chrystusa, uznać Go za najwyższą wartość, wobec której wszystko inne wydaje się bez znaczenia: „Dla Niego wyzułem się ze wszystkiego, bylebym pozyskał Chrystusa por. Flp 3, 8). Czasownik dzemioomai, przetłumaczony w Biblii Tysiąclecia jako „wyzułem się”, jest różnie tłumaczony: „zrezygnowałem, straciłem, wycierpiałem stratę wszystkiego, zgodziłem się wszystko stracić". Ten sam czasownik występuje w Mk 8, 36: „Cóż bowiem za korzyść stanowi dla człowieka zyskać świat cały, a swoją duszę utracić?”.

Paweł, można by rzec, przyjmuje ostrzeżenie Jezusa: traci wszystko, ale wyraźnie wskazanym celem jest nie tyle ocalenie duszy, ile raczej „zdo-

4 Por. J. Flis, List do Filipian, Częstochowa 2011, s. 244 (Nowy Komentarz Biblijny, 11). 
bycie Chrystusa", a dotychczasowe wartości (duma z pochodzenia czy wzorowego postępowania) stają się dla Pawła skybala - gnojem, śmieciami, tym, co wyrzuca się psom.

Zauważono też - oczywiście, z zachowaniem należnych proporcji i z uwzględnieniem różnicy sytuacji -iżten sam czasownik wyraża postawę Chrystusa, który, jak czytamy w Flp 2, 6, „nie uważał (hegesato) swej równości z Bogiem za zazdrośnie trzymany skarb", i postawę Pawła, który uznaje (hegemai) za stratę to, co dawniej było dla niego wielką wartością (por. Flp 3, 7) .

Niegdyś dumny faryzeusz, teraz przedstawia się jako „sługa Jezusa Chrystusa". Zrozumiejmy dobrze ten tytuł, bowiem w naszych uszach brzmi on zaszczytnie; pamiętajmy, że w czasach Pawła bycie sługą - doulos oznaczało sytuację najdalszą od wszelkich zaszczytów: doulos to ktoś, kto nie należy do siebie, ale do swojego wyłącznego pana; to pan dysponuje wszystkim, co sługa posiada, nawet jego rodziną. Owoce pracy sługi, a nawet jego dzieci, są własnością pana. To nie przypadek, że właśnie w cytowanym wyżej Flp 3 Paweł nazwie Chrystusa „mój Pan”.

Wracając do użytego wyżej obrazu, Paweł zrobił w sobie miejsce dla Chrystusa, co przyniosło owoce nie tylko w jego życiu, ale i w życiu wiernych: „żyję już nie ja, lecz żyje we mnie Chrystus” (Ga 2, 20); ,spodobało się Temu, który wybrał mnie jeszcze w łonie matki mojej i powołał łaską swoją, aby objawić Syna swego we mnie" (Ga 1,15n).

Paweł jest jednak nie tylko sługą Chrystusa, ale też i wiernych, do których Chrystus go posłał: „stałem się niewolnikiem wszystkich, aby tym liczniejsi byli ci, których pozyskam" (1 Kor 9, 19). Widać to wyraźnie w jego dialogu z Koryntianami skłonnymi do nadmiernego przywiązywania się do osoby, przez którą poznali Chrystusa (,ja jestem Pawła, ja Apollosa..."). Paweł wyczuwa niebezpieczeństwo, iż relacja pomiędzy wiernymi a głosicielem Ewangelii może zacząć przypominać typową dla starożytnego świata relację klienteli i dlatego odwraca wypowiedź Koryntian: „Czy to Paweł, czy Apollos, czy Kefas; wszystko jest wasze, wy

Por. A. Pitta, Lettera ai Filippesi, Milano 2010, s. 233 (I Libri Biblici. Nuovo Testamento, 11).

6 Por. R. Penna, Paolo come schiavo apostolico e l'identità ministeriale della Chiesa nella Lettera ai Romani, [w:] Chiesa e ministeri in Paolo, a cura di G. De Virgilio, Bologna 2003, s. 16. 
zaś Chrystusa, a Chrystus - Boga” (1 Kor 3, 21nn). Inaczej mówiąc: to nie wy, Koryntianie, jesteście Pawła czy Apollosa, ale oni są wasi, są „sługami, poprzez których uwierzyliście" (1 Kor 3, 5).

Kto nazywa się sługą, nie dziwi się, gdy przychodzi mu żyć w ciężkich warunkach: „Umiem cierpieć biedę, umiem też korzystać z obfitości. Do wszystkich w ogóle warunków jestem zaprawiony: i być sytym, i głód cierpieć, korzystać z obfitości i doznawać niedostatku. Wszystko mogę w Tym, który mnie umacnia" (Flp 4, 12n).

Paweł wie, że musi zgodzić się na różne formy ogołocenia, ubóstwa, upokorzenia, aby jego działalność apostolska przyniosła obfite owoce. Tak pisze ironicznie do tych Koryntian, którzy naiwnie wierzyli, iż osiągnęli już ostateczny cel życia chrześcijańskiego: „Tak więc już jesteście nasyceni, już opływacie w bogactwa. Zaczęliście królować bez nas! Otóż tak! Nawet trzeba, żebyście królowali, byśmy mogli współkrólować z wami. Wydaje mi się bowiem, że Bóg nas, apostołów, wyznaczył jako ostatnich, jakby na śmierć skazanych. Staliśmy się bowiem widowiskiem dla świata, aniołów i ludzi; my głupi dla Chrystusa, wy mądrzy w Chrystusie, my niemocni, wy mocni; wy doznajecie szacunku, a my wzgardy" (1 Kor 4, 8n). Właśnie w takich warunkach Apostoł pełni funkcję szafarza Bożych darów. Podobnie jak Jego Mistrz, tak i Paweł uniża się, by poprzez swoje ubóstwo ubogacić wiernych Bożym bogactwem: ,jakby ubodzy, a jednak wzbogacający wielu, jako ci, którzy nic nie mają, a posiadają wszystko” (2 Kor 6, 10). To jest bowiem sekret tej „mocy, która doskonali się w słabości" (por. 2 Kor 12, 9): gdyby wierni słuchali kogoś, kto jest szanowany, zamożny, atrakcyjny, nie można by mieć pewności, czy przyjęcie takiego mówcy nie byłoby oparte na czysto ludzkich przesłankach. Jeśli natomiast przyjmują kogoś wyśmiewanego, oczernianego, prześladowanego i rozpoznają w jego nauczaniu słowo Boga, to widać, że działała w nich moc Ducha. Paweł nie zostawia złudzeń co do warunków pracy apostolskiej, także pod względem materialnym: „Aż do tej chwili łakniemy i cierpimy pragnienie, brak nam odzieży”; „żyjemy w niedostatku, lecz nie rozpaczamy” (1 Kor 4, 11; 2 Kor 4, 8). Ale właśnie przez te warunki Apostoł staje się bliższy cierpiącym wiernym, lepiej rozumie ich udręki: „Któż odczuwa słabość, bym i ja nie czuł się słaby?" (2 Kor 11, 29). 
Jednak fakt, iż niedostatek jest częstym udziałem głosiciela Ewangelii, nie oznacza, że na wspólnocie, której głosi on słowo, nie spoczywa obowiązek zadbania o jego utrzymanie. Warto o tym pamiętać, bowiem niekiedy, skupiając się wyłącznie na postawie samego Pawła, dochodzi się do błędnego wniosku, jakoby jego zdaniem wierni byli zwolnieni od odpowiedzialności za byt materialny misjonarza, który ma sam zarobić na swoje utrzymanie. Tymczasem Paweł mówi wyraźnie: „Jeżeli więc my zasialiśmy wam dobra duchowe, to cóż wielkiego, że uczestniczymy w żniwie waszych dóbr doczesnych? [...] Pan postanowił, ażeby z Ewangelii żyli ci, którzy głoszą Ewangelię" (1 Kor 9, 11. 14). Natomiast sam Paweł (i zapewne też towarzyszący mu współpracownicy - por. 1 Kor 9,12) nie korzysta z tej możliwości, pamiętając, jak łatwo staje się przedmiotem ataku przeciwników ze względu na swoją szczególną sytuację apostoła powołanego dopiero przez Zmartwychwstałego Pana. Paweł pracuje na swoje utrzymanie, by nikt nie mógł mu zarzucić, że działa dla zysku i wykorzystuje wiernych. Podaje też inne motywy swojego postępowania: „Pracowaliśmy w trudzie i zmęczeniu, we dnie i w nocy, by dla nikogo z was nie być ciężarem [...] po to, aby dać wam samych siebie za przykład do naśladowania” (2 Tes 3, 8n); „Nie będę was obciążał [...] Nie dzieci rodzicom winny gromadzić majętności, lecz rodzice dzieciom" (2 Kor 12, 14)7.

Jak wiadomo, jedynie od najwierniejszych mu Filipian Paweł przyjmował pomoc materialną i cieszył się nią: „Wy, Filipianie, wiecie przecież, że na początku [głoszenia] Ewangelii, gdy opuściłem Macedonię, żaden z Kościołów poza wami jednymi nie prowadził ze mną otwartego rachunku przychodów i rozchodów, bo do Tesaloniki nawet raz i drugi przysłaliście na moje potrzeby. Mówię zaś to bynajmniej nie dlatego, że pragnę daru, lecz pragnę owocu, który wzrasta na wasze dobro" (Flp 4,15-17). W ostatnich słowach Pawła pojawia się motyw, który dostrzeżemy, mówiąc o składce dla ubogich z Jerozolimy: ofiarność, wyrzeczenie tworzą pewnego rodzaju kapitał dobra, które jest przekazywane dalej, a zarazem wraca do ofiarodawcy. Ubóstwo ubogaca nie

Aby zamknąć temat owoców płynących z pracy, warto dodać, że w Ef 4, 28, mówiąc już nie o głosicielach Ewangelii, a o ...byłych złodziejach, Paweł zaleci im uczciwą pracę, by mieć „z czego użyczać potrzebującemu”. 
tylko innych, ale i tego, kto je podjął, bo w zamian za dobra materialne otrzymuje się dobra duchowe.

\section{Troska o ubogich}

Wypowiedzi Pawłowe dotyczące troski o ubogich (mam tu na myśli różne rodzaje ubóstwa, nie tylko materialne) są osadzone w jego wizji Kościoła jako jednego ciała, Mistycznego Ciała Chrystusa. Paweł zakłada, że pewne naturalne prawa obowiązujące w ludzkim organizmie powinny siłą rzeczy znaleźć swe odzwierciedlenie w Ciele Mistycznym. „Te [członki ciała], które uważamy za mało godne szacunku, tym większym obdarzamy poszanowaniem [...] Bóg tak ukształtował nasze ciało, że zyskały więcej szacunku członki z natury mało godne czci, by nie powstało rozdwojenie w ciele, lecz żeby poszczególne członki troszczyły się o siebie nawzajem. Tak więc, gdy cierpi jeden członek, współcierpią wszystkie inne członki; podobnie gdy jednemu członkowi okazywane jest poszanowanie, współradują się wszystkie członki” (1 Kor 12, 22n). Widać tu wyraźnie, jak „prawo ludzkiego organizmu” działa zupełnie inaczej niż prawa kierujące społeczeństwami zarówno w starożytności, jak i obecnie, gdzie liczy się ten, kto jest najsilniejszy, najbardziej ceniony. Tymczasem ludzkie ciało - i trzeba, by podobnie działało Ciało Mistyczne - prawidłowo funkcjonuje tylko wtedy, gdy otacza największą troską to, co najsłabsze i co po ludzku najmniej zasługuje na szacunek.

Wcześniej w tym samym liście Paweł zarzucał Koryntianom, że ich zebrania, łączące, jak wiadomo, agapę z Eucharystią, nie są godne miana Wieczerzy Pańskiej, gdyż bogaci nie czekają na ubogich, sami rozpoczynają agapę i w efekcie ubodzy nie mogą się posilić tym, co zostało przyniesione przede wszystkim ze względu na nich. Jak można w takich warunkach celebrować sakrament jedności Chrystusa z wiernymi oraz wiernych między sobą? Paweł napisze zdanie, które często rozumie się jedynie w sensie należnego szacunku do Eucharystii i godnego Jej przyjmowania: „Kto bowiem spożywa i pije, nie zważając na Ciało [Pańskie], wyrok sobie spożywa i pije" (1 Kor 11, 29). Wydaje się jednak, że sens tego zdania jest znacznie szerszy: przeżywanie Eucharystii jest niegodne nie 
tylko wtedy, gdy nie zważa się na Eucharystyczne Ciało Chrystusa (brak szacunku dla Jego obecności), ale też gdy znieważa się Jego ciało eklezjalne, lekceważąc najsłabsze Jego członki.

Znamienna jest też troska i wyrozumiałość, jaką Paweł zaleca również wobec słabszych braci, jak trafnie określa ich Alessandro Sacchi - „uboższych pod względem ekonomicznym i intelektualnym, przeżywających swoją wiarę w sposób prosty i spontaniczny, niosąc ze sobą uwarunkowania wcześniejszych doświadczeń"; ; ci bracia gorszą się, gdy ich współwyznawcy jedzą potrawy zakazane przez Prawo Mojżeszowe albo mięso, które wcześniej było złożone w ofierze bożkom pogańskim. Nakazując uwzględniać racje sumienia tych słabych braci i nie gorszyć ich, Apostoł podaje niepodważalne dowody wielkiej wartości każdego z członków wspólnoty: są to bracia, „za których umarł Chrystus” i których „Bóg łaskawie przygarnął”; zatem nie wolno psuć Bożego dzieła w ich duszach. „Ten, kto jada [wszystko], niech nie pogardza tym, który nie [wszystko] jada, a ten, który nie je, niech nie potępia tego, który je; bo Bóg go łaskawie przygarnął. Kim jesteś ty, co się odważasz sądzić cudzego sługę?" (Rz 14, 3n); „Baczcie jednak, aby to, iż wiecie, [jak należy postępować,] nie stało się dla słabych powodem do zgorszenia. Gdyby bowiem ujrzał ktoś ciebie, oświeconego wiedzą, jak zasiadasz do uczty bałwochwalczej, czy to nie skłoni również kogoś o słabszym sumieniu do spożywania z ofiar składanych bożkom? I tak to właśnie wiedza twoja sprowadza zgubę na słabego brata, za którego umarł Chrystus" (1 Kor 8, 9-11).

Ta głęboka troska o jedność Kościoła i o poszanowanie ubogich pod każdym względem tkwi również u podstaw wielkiego przedsięwzięcia, na którym Pawłowi szczególnie zależy, gdy pisze listy do Koryntian i do Rzymian: chodzi o składkę na rzecz ubogich z Jerozolimy. Apostoł tak tłumaczy Rzymianom fundamentalną rację tej zbiórki darów: „Macedonia i Achaja bowiem uznały za stosowne zebrać składkę na rzecz świętych w Jeruzalem. Uznały za stosowne, bo i są ich dłużnikami. Jeżeli bowiem poganie otrzymali udział w ich dobrach duchowych, powinni im za to służyć pomocą doczesną" (Rz 15, 26n). A do samych Koryntian pisze:

8 A. Sacchi, Le lettere autentiche, [w: Lettere Paoline e altre lettere, a cura di A. Sacchi, Torino 1995, s. 111. 
„Teraz więc niech wasz dostatek przyjdzie z pomocą ich potrzebom, aby ich bogactwo było wam pomoca w waszych niedostatkach i aby nastała równość, jak to jest napisane: Nie miał za wiele ten, kto miał dużo. Nie miał za mało ten, kto miał niewiele" (2 Kor 8, 14n). Nieprzypadkowo Paweł przytacza zdanie Wj 16, 18 odnoszące się do manny: hojność w składce jest też przejawem zaufania do Boga, który troszczy się o swoich wiernych, jak to wyraźnie okazał podczas wędrówki Izraela przez pustynię.

Paweł pragnie, by składka była dowodem troski wspólnot poganochrześcijańskich o Kościół - Matkę w Jerozolimie. Zdumiewa rozmach, z jakim Paweł organizuje składkę: dla potrzebujących z jednego miasta zbierają dary wierni z kilku regionów nad Morzem Egejskim; to wskazuje, jak ważne było dla Pawła budowanie poczucia wzajemnej odpowiedzialności ${ }^{9}$, a także zapewne przekonanie do swego dzieła tych judeochrześcijan, którzy patrzyli niechętnym okiem na zbyt liberalne, ich zdaniem, zasady przyjmowania pogan do Kościoła.

Warto zwrócić uwagę na niezwykle ciekawe określenia, jakimi Paweł nazywa to - zdawałoby się - przyziemne i banalne przedsięwzięcie, bowiem wiążą się one ściśle z tematem naszych rozważań.

Terminem pojawiającym się zadziwiająco często w 2 Kor 8 i 9 jest charis - łaska. James R. Harrison słusznie dostrzega w 2 Kor 8-9 „trójwymiarowe pojęcie łaski"10. 0 pierwszym wymiarze łaski mówiliśmy na początku - chodzi o ubogacenie wiernych przez ubóstwo Chrystusa: „znacie łaskę Pana naszego...”. Odpowiedzią wiernych jest nie tylko wdzięczność wobec samego Boga, ale czynne okazywanie tej wdzięczności poprzez hojność wobec braci, co również jest określone słowem „łaska”: „A podobnie jak obfitujecie we wszystko, w wiarę, w mowę, w wiedzę, we wszelką gorliwość, w miłość naszą do was, tak też obyście i w tę łaskę obfitowali" (2 Kor 8, 7). Wierny okazujący ofiarną miłość wobec braci staje się przekazicielem otrzymanej łaski od Boga. Oto paradoks: obfitować w łaskę, rezygnując z części własnego bogactwa! Ale właśnie tak okazuje się wdzięcz-

9 Por. J. D. G. Dunn, Gli albori del cristianesimo. 2. Gli inizi a Gerusalemme, vol. 2: Paolo, apostolo dei gentili, Brescia 2012, s. 950.

10 J. R. Harrison, Paul's Language of Grace in its Graeco-Roman Context (Ph.D. thesis), Sydney 1996, § 7,2; cyt. za: J. D. G. Dunn, La teologia dell'apostolo Paolo, Brescia 1999, s. 679. 
ność za otrzymane dary Temu, który nie da się prześcignąć w hojności: „A Bóg może zlać na was całą obfitość łaski, tak byście mając wszystkiego i zawsze pod dostatkiem, bogaci byli we wszystkie dobre uczynki”. Jest jeszcze dodatkowy owoc składki: jej przekaziciele wielbią Boga i modlą się za ofiarodawców , z powodu przebogatej w was łaski Boga” (2 Kor 9, 14).

Zatem przez ubóstwo Chrystusa spłynęły na wiernych duchowe dary, a oni, widząc, jak wiele otrzymali, winni okazać podobną hojność wobec potrzebujących. Ta hojność zostanie nagrodzona nowymi Bożymi łaskami, a przekaz darów stanie się okazją do wielbienia Boga.

Inne słowo występujące w tych rozdziałach 2 Kor to obfitość (perisseuma). Paweł prosi o obfitość składki jako odpowiedź na hojność Chrystusa, jako „właściwą odpowiedź ze strony tych, którzy otrzymali tak wiele”11. Apostoł nie wymaga jednak przesadnej, nieroztropnej hojności: „Nie o to bowiem idzie, żeby innym sprawiać ulgę, a sobie utrapienie, lecz żeby była równość" (2 Kor 8, 13).

Kolejnym ciekawym określeniem składki, które w dzisiejszych czytelnikach może budzić błędne skojarzenia, jest leitourgia, która w tamtych czasach nie oznaczała jednak czynności kultycznej, ale służbę publiczną (choć może ona także dotyczyć spraw związanych z kultem). Co ciekawe, tę służbę publiczną pełniły osoby bogate na własny koszt, zatem zapewne tylko nieliczni chrześcijanie Koryntu mogliby pełnić ją na rzecz swojego miasta. Paweł jednak chce podkreślić, że nawet ci, którzy nie są zbyt zamożni materialnie, zostali ubogaceni łaską Boga, są więc duchowo bogaci i mogą czynić dobro dla ubogich braci w wierze ${ }^{12}$.

Apostoł wykazuje wiele sprytu, oddziałując na ambicję Koryntian stwierdzeniem, że przekazana Macedończykom wiadomość, iż Achaja (a zatem i Korynt) już zebrała składkę, pobudziła Macedończyków - uboższych od Koryntian - do współzawodnictwa; prosili oni o możliwość udziału w tej łasce i okazali się hojni ponad możliwości; byłoby więc wielkim wstydem, gdyby wysłannicy z Macedonii przekonali się o opieszałości Koryntian.

W listach do Koryntian widzimy więc wielki zapał Pawła do dzieła składki, ale w Liście do Rzymian Apostoł dzieli się z wiernymi pewną obawą:

11 J. D. G. Dunn, La teologia dell'apostolo Paolo, dz. cyt., s. 954.

12 Por. J. D. G. Dunn, Gli albori..., dz. cyt. s. 955. 
„Proszę więc was, bracia, [...] abyście udzielili mi wsparcia modłami waszymi za mnie do Boga, abym wyszedł cało z rąk niewiernych w Judei i by moja posługa na rzecz Jeruzalem została dobrze przyjęta przez świętych"

Komentatorów zadziwia milczenie Łukasza na temat składki, gdy opisuje on pobyt Pawła w Jerozolimie. Wielu uważa, że skoro subtelny Łukasz nic nie mówi o przyjęciu darów, być może oznacza to, że zwierzchnicy Kościoła jerozolimskiego obawiali się, iż przyjmując przywiezione dary, będą podejrzewani przez bardziej konserwatywną część judeochrześcijan o popieranie liberalnej linii Pawła. Przypuszczalnie dlatego zaproponowali Pawłowi, by przeznaczył część składki na pokrycie kosztów ofiary czterech Żydów, którzy złożyli ślub; gdy Paweł udowodni w ten sposób swoją wierność zwyczajom przodków, składka będzie mogła być przyję$\mathrm{ta}^{13}$. Wiemy jednak, że wydarzenia przybrały zupełnie inny obrót. O nieprzyjęciu składki może też ewentualnie świadczyć oczekiwanie namiestnika Feliksa, iż dostanie pieniądze od Pawła (por. Dz 24, 28). Jeśli tak było rzeczywiście, łatwo zrozumieć, jak bolesne dla Apostoła musiało być to odrzucenie: nie oznaczało ono jedynie zakwestionowania jego osoby i sposobu postępowania, ale budziło obawy o dalszą jedność między judeo- i poganochrześcijanami.

Na koniec trzeba wspomnieć o jedynych, jak już wyżej powiedziano, typowych radach dotyczących ubóstwa i bogactwa, jakie znajdujemy w listach Pawłowych, choć czytamy je w 1 Liście do Tymoteusza, co do którego autorstwo Pawłowe jest bardzo niepewne. Autor zaleca Tymoteuszowi, by nakazywał bogatym pokładanie ufności w Bogu, a nie w niepewnym bogactwie, by wyróżniali się hojnością i troską o innych (por. 1 Tm 6,17n). Podkreśla też złoty umiar i ostrzega przed pułapką chciwości. „Wielkim zaś zyskiem jest pobożność w połączeniu z poprzestawaniem na tym, co się ma. Nic bowiem nie przynieśliśmy na ten świat; nic też nie możemy [z niego] wynieść. Mając natomiast żywność i odzienie, i dach nad głową, bądźmy z tego zadowoleni. A ci, którzy chcą się bogacić, popadają w pokusę i w zasadzkę diabła oraz w liczne nierozumne i szkodliwe pożądania. [...] Albowiem korzeniem wszelkiego zła jest

13 Por. R. Fabris, Paolo. L'Apostolo delle genti, Torino 1997, s. 447. 
chciwość pieniędzy. Za nimi to uganiając się, niektórzy zbłądzili z dala od wiary i sobie samym zadali wiele cierpień" (1 Tm 6, 6-10).

W rozdziale 5 tego samego listu znajdujemy kolejne - po Dz 6 potwierdzenie, iż Kościół otaczał szczególną opieką wdowy. Już w wielu tekstach Starego Testamentu zaleca się troskę o ubogie wdowy, których sytuacja była wyjątkowo trudna, jeśli nie mogły liczyć na wsparcie rodziny (pamiętajmy, że Prawo nie przewidywało dziedziczenia przez wdowę majątku męża!). Autor Listu zaleca więc Tymoteuszowi tę troskę, podkreślając jednak, by pomagał tym, „które rzeczywiście są wdowami” i nie mogą liczyć na inną pomoc, co wskazuje, że już w pierwotnym Kościele istniało niebezpieczeństwo nieuczciwego wykorzystywania działalności dobroczynnej Kościoła.

Łatwo zauważyć, jak interesujące nas treści zawarte w 1 Tm różnią się od tych, które znajdujemy w listach protopawłowych. W swoich autentycznych listach Paweł bowiem woli mówić o ubóstwie w kluczu chrystologiczno-eklezjologicznym jako pewnym paradoksalnym warunku przyjęcia darów Bożych we własnym życiu i skutecznej ewangelizacji aniżeli w kluczu społeczno-moralnym jako zachęcie do poprawy losu ubogich. Podobnie bogactwo najczęściej nie jest przedmiotem krytyki jako chciwe posiadanie dóbr zdobytych niekoniecznie uczciwą drogą, ale występuje przede wszystkim jako przymiot Boga, który obdarza nim swoich wiernych. Słusznie zauważa Thomas E. Schmidt, że podobnie jak wartości tego świata zostają przemienione w Chrystusie, tak też i słownik tego świata potrzebuje nowego sformułowania ${ }^{14}$. Zatem aby właściwie odczytać myśl Apostoła, Narodów w kwestii ubóstwa i bogactwa, trzeba unikać stereotypów i uproszczeń, jakimi sprowadzamy te pojęcia do tylko jednego wymiaru. Bowiem zysk może być stratą, strata może być zyskiem. Trzeba umieć stracić, by przyjąć prawdziwe bogactwo i móc ubogacić innych. Taka jest logika Ewangelii.

14 T. E. Schmidt, Ricchezza e povertà, [w:] Dizionario di Paolo e delle sue opere, a cura di G. F. Hawthorne, R. P. Martin, D. G. Reid, Cinisello Balsamo 1999, s. 1329. 


\section{Summary}

„Ubodzy, a wzbogacający wielu” (por. 2 Kor 6, 10). Ubóstwo Chrystusa i wiernych w nauczaniu św. Pawła

W tradycyjnie pojmowanym zbiorze Listów Pawłowych jedynie w 1 Tm można znaleźć typowe wskazania dotyczące ewangelicznej postawy wobec dóbr materialnych. W listach protopawłowych myśl Apostoła rozwija się w innym kierunku: wzorem dla wiernych i punktem wyjścia jest uniżenie, ogołocenie Chrystusa, który właśnie poprzez przyjęcie ludzkiej natury obdarzył nas życiem Bożym. Paweł wpatrzony w ten wzór również „wyzuł się ze wszystkiego”, by wytworzyć w swoim życiu „przestrzeń” dla Chrystusa, aby On poprzez Apostoła mógł działać w wiernych. Na wzór Chrystusa Sługi również Paweł czuje się sługą, nie tylko swojego Pana, ale i powierzonych mu braci $\mathrm{w}$ wierze. Zachęca ich do wzajemnej troski i współodpowiedzialności, przypominając, iż w Chrystusie wszyscy - także, a może zwłaszcza ci najsłabsi - są członkami jednego Mistycznego Ciała, a nawet najuboższy członek wspólnoty ma bezcenną wartość, skoro Chrystus przelał za niego swoją krew. Konkretnym przejawem troski Apostoła o dobro i jedność całego Kościoła jest organizacja składki wśród wspólnot znad Morza Egejskiego dla ubogich wiernych w Jerozolimie. Paweł pragnie, by wierni traktowali udział w składce nie jako bolesne wyrzeczenie, ale jako udział w łasce, jako dowód wdzięczności wobec Boga, który nie da się prześcignąć w hojności.

Słowa kluczowe: Paweł, ubóstwo, bogactwo, wierni, składka

As Poor yet Making Many Rich (2 Cor 6, 10). The Poverty of Christ and His Believers in the Teaching of St. Paul

In a traditional collection of The Epistles of Paul only the First Epistle of Paul to Timothy contains typical hints concerning the evangelic attitude towards material goods. In Proto-Pauline letters the Apostle's thought is developed in a different direction: it is Christ's humility and emptying himself which is the model for the believers and the starting point. It was through adopting human nature that Christ granted us life in God. Following this example Paul also "deprived himself of everything" to make "space" for Christ in his life and to let Christ act through him. Following the example of Christ-Servant Paul also considers himself a servant, not only of his Lord but also a servant of his brothers in faith entrusted to him. He encourages them to care about one another and to share responsibility, reminding them that all people, especially the weakest, are members of Christ Mystical Body. Even the poorest member of community is of invaluable worth since Christ shed His blood for him. The Apostle organizes collection of donations among communities at Aegean Sea for poor believers in Jerusalem, which is a clear indication of his care about the good and unity of all 
Church. Paul wishes the faithful to treat giving donations not as a painful sacrifice but as taking part in grace, as a proof of thankfulness towards God, who cannot be surpassed when it comes to generosity.

Keywords: Paul, poverty, richness, believers, collection

\section{Bibliografia}

F. Bianchini, Lettera ai Filippesi, Milano 2010 (Nuova Versione della Bibbia dai Testi Antichi, 47).

J. D. G. Dunn, La teologia dell'apostolo Paolo, Brescia 1999.

J. D. G. Dunn, Gli albori del cristianesimo. 2. Gli inizi a Gerusalemme, vol. 2, Paolo, apostolo dei gentili, Brescia 2012.

R. Fabris, Paolo. L'Apostolo delle genti, Torino 1997.

J. Flis, List do Filipian, Częstochowa 2011 (Nowy Komentarz Biblijny, 11).

G. Lorusso, La Seconda Lettera ai Corinzi, Bologna 2007 (Scritti delle Origini Cristiane, 8).

A. Pitta, Lettera ai Filippesi, Milano 2010 (I Libri Biblici. Nuovo Testamento, 11).

R. Penna, Paolo come schiavo apostolico e l'identità ministeriale della Chiesa nella Lettera ai Romani, [w:] Chiesa e ministeri in Paolo, a cura di G. De Virgilio, Bologna 2003, s. 15-36.

A. Sacchi, Le lettere autentiche, [w:] Lettere Paoline e altre lettere, a cura di A. Sacchi, Torino 1995, s. 83-188.

T. E. Schmidt, Ricchezza e povertà, [w:] Dizionario di Paolo e delle sue opere, a cura di G. F. Hawthorne, R. P. Martin, D. G. Reid, Cinisello Balsamo 1999, s. 1328-1331. 